\title{
VULNERABILITY MAPPING OF KARST SPRINGS AND ITS APPLICATION FOR THE DELINEATION OF PROTECTION ZONES (MECSEK KARST, HUNGARY)
}

\author{
KARTIRANJE RANLJIVOSTI KRAŠKIH IZVIROV IN UPORABA \\ TEGA ZA DOLOČITEV VODOVARSTVENIH OBMOČIJ \\ (KRAŠKO POGORJE MECSEK, MADŽARSKA)
}

\author{
Éva FARICS ${ }^{1 *}$, Amadé HALÁSZ ${ }^{1}$, Szabolcs CZIGÁNY² \& Ervin PIRKHOFFER ${ }^{2}$
}

\begin{abstract}
UDC 551.44:556.36:528.9(234.373.6)

Éva Farics, Amadé Halász, Szabolcs Czigány \& Ervin Pirkhoffer: Vulnerability mapping of karst springs and its application for the delineation of protection zones (Mecsek Karst, Hungary)

Over the past decade or two, vulnerability mapping become a useful tool to determine the sensitivity of karst aquifers and allows the analysis of karstic aquifers affected by human activities. The Tettye Catchment, one of the eight catchments of the Mecsek Karst aquifer (SW Hungary), supplies drinking water for Pécs, the fifth most populous city in Hungary. However, due to its partly urbanized character and heterogeneous karstic features, this catchment is highly sensitive to anthropogenic impacts. In this study we aimed to generate resource vulnerability maps and risk maps to assess the role of physical and anthropogenic factors on groundwater vulnerability in the Mecsek Karst. Two formerly validated methods were used, the COP (Concentration, Overlaying layers and Precipitation) and SA (Slovene Approach) methods. The resource vulnerability maps, validated by former tracer tests, were combined with the hazard map obtained from the COST action 620 and EU Water Directive to generate risk maps. Tracer-based transit times were commonly less than 20 days in the majority of the areas of extreme vulnerability. During the current study, a new protocol has been elaborated for the delineation of the protection zones of karstic aquifers. Comparing the two methods, the SA performed better in terms of intrinsic vulnerability mapping, as it had a higher spatial resolution and was more detailed than the COP map and had a more sophisticated vulnerability indexing. In addition, high spatial correlation was revealed between the transit time maps and the SA map. Reassessed risk zonation, with appropriate legal consequences, likely minimizes undesired hu-
\end{abstract}

\begin{abstract}
Izvleček
UDK 551.44:556.36:528.9(234.373.6)

Éva Farics, Amadé Halász, Szabolcs Czigány \& Ervin Pirkhoffer: Kartiranje ranljivosti kraških izvirov in uporaba tega za določitev vodovarstvenih območij (kraško pogorje Mecsek, Madžarska)
\end{abstract}

V zadnjem desetletju ali dveh je kartiranje ranljivosti postalo uporabno orodje za določanje ranljivosti kraških vodonosnikov, poleg tega omogoča analizo kraških vodonosnikov, na katere vplivajo človekove dejavnosti. Zaledje izvira Tettye, eno od osmih zaledij vodonosnika kraškega pogorja Mecsek (jugozahodna Madžarska), oskrbuje s pitno vodo mesto Pécs, peto mesto na Madžarskem po številu prebivalcev. Zaradi svoje delne urbaniziranosti in heterogenih kraških značilnosti pa je to zaledje zelo občutljivo na antropogene učinke. Cilj te študije je bil izdelati karte ranljivosti vodnih virov in karte tveganja za oceno, kakšno vlogo imajo fizični in antropogeni dejavniki na ranljivost podzemne vode na kraškem pogorju Mecsek. Uporabljeni sta bili dve predhodno potrjeni metodi, in sicer metoda COP (koncentracija toka, prekrivne plasti in padavine) in metoda Slovenski pristop. Karte ranljivosti vodnih virov, preverjene s predhodnimi sledilnimi poskusi, so bile združene s kartami obremenjevalcev, narejenimi na podlagi Okvirne vodne direktive Evropske unije oziroma projekta COST Action 620, da so nastale karte tveganja. Zadrževalni časi, pridobljeni na podlagi sledilnih poskusov, so bili na večini območij izjemne ranljivosti običajno krajši od 20 dni. V okviru te študije je bil izdelan nov protokol za določanje vodovarstvenih območij kraških vodonosnikov. Iz primerjave obeh metod je razvidno, da se je Slovenski pristop bolje obnesel z vidika kartiranja naravne ranljivosti, saj je imel višjo prostorsko ločljivost in je bil podrobnejši kot zemljevid po metodi COP, poleg tega je imel bolj izpopolnjeno indeksiranje ranljivosti. Ob tem je bila razkrita visoka prostor-

\footnotetext{
${ }^{1}$ Department of Geology and Meteorology, University of Pécs, Ifjúság útja 6, H-7624 Pécs, Hungary, e-mails: faricse@gamma.ttk.pte.hu, tade@gamma.ttk.pte.hu

2 Department of Physical and Environmental Geography, University of Pécs, Ifjúság útja 6, H-7624 Pécs, Hungary, e-mail: sczigany@gamma.ttk.pte.hu,pirkhoff@gamma.ttk.pte.hu

* Corresponding Author
} 
man activities within the zone of protection, hence maintaining water quality that complies with the protection acts.

Keywords: COP, Slovene Approach, Mecsek Karst System, vulnerability, risk intensity, GIS. ska korelacija med kartami potovalnih časov in karto po Slovenskem pristopu. Ponovno ocenjeno coniranje tveganja $\mathrm{z}$ ustreznimi pravnimi posledicami verjetno zmanjšuje nezaželene človekove dejavnosti na varovanem območju, s čimer se ohranja kakovost vode, kar je skladno s predpisi o varovanju.

Ključne besede: COP, Slovenski pristop, sistem kraškega pogorja Mecsek, ranljivost, intenzivnost tveganja, GIS.

\section{INTRODUCTION}

Nowadays, there is a need to reconcile human activities with the sustainable use of drinking water resources (Adams \& Foster, 1992; Foster et al., 2013). According to the Water Framework Directive (WFD) on groundwater (European Commission, 2007), the delimitation of catchment areas and the design of protection zones of aquifers are among the most important tasks of today and the future. The Hungarian environmental protection zonation act (123/1997. (VII. 18.)) is uniformly applied on the vulnerability zonation of aquifers, drinking water supplies and natural water bodies. Therefore, in Hungary, no karst-specific vulnerability zonation exists.

Groundwater resources, among which karst water is of the highest quality, have an increasing role on drinking water supply in Europe (Hartmann et al., 2014; Stevanovic, 2019), including Hungary, where $25 \%$ of drinking water is supplied from karst aquifers (Barreto et al., 2017). In the city of Pécs (located on the southern slopes of the Mecsek Hills) about $1 / 3$ of the drinking water is supplied from the Danube, a second 1/3 from Miocene porous clastic sediments, while the remaining roughly $1 / 3$ is from the Tettye Aquifer. However, water storage depends on the functioning of the entire karst hydrogeological system, which is part of the complex karst ecosystems often exposed to extreme environmental pressure. For a variety of reasons, karst aquifers are very sensitive to contamination (Ford \& Williams, 1989; Zwahlen, 2004) due to the rapid recharge via sinkholes, high flow velocities and short residence times (Goldscheider, 2010). For this reason, COST Action 620 developed a general conceptual framework for vulnerability and risk mapping (Daly et al., 2002; Zwahlen, 2004).

Margat (1968) and Albinet \& Margat (1970) introduced the concept of the vulnerability of groundwater to contamination. The groundwater vulnerability concept embraces two groups of factors: the first one, prevailingly at macroscale, focuses on the hydraulic properties of the surrounding medium, and mobility of the pollutants into the aquifer. The second group of factors focus on the physico-chemical and interfacial processes physico-chemical processes, like adsorption, diffusion and advection, which determines pollutant mobility at meso- and microscales (Foster, 1987). In practice, vulnerability is enhanced by the poor soil filter or filtering in karst passages, the intricate paths of pollution spreading within a communicating hydrogeological system, where water flow is relatively rapid and hidden from observers on the surface (Lóczy, 2006). Vulnerability mapping has become an expedient tool to identify protection zones for karst aquifers. Several methods have been developed: EPIK (Dörfliger \& Zwahlen, 1998), PI (Goldscheider et al., 2000), KARSTIC (Davis et al., 2002); COP and COP + K methods (Vías et al., 2006; Andreo et al., 2009), Slovene Approach - SA (Ravbar \& Goldscheider, 2007), PaPRIKa (Kavouri et al., 2011). Today, GIS-based approaches are widely used (Jeannin et al., 2013; Hartmann et al., 2014; Turk et al., 2014). Intrinsic vulnerability is described as the sensitivity to contamination of a karst aquifer, considering its geological, hydrological and hydrogeological characteristics. The intrinsic vulnerability mapping is supplemented mostly with risk assessment (Ravbar \& Goldscheider, 2007).

In Hungary karst vulnerability has been mapped for the Keszthely Mountains, a member of the

Transdanubian Mountains (Szőnyi-Mádl \& Füle, 1998), the Little Plateau of the Bükk

Mountains in the North-Hungarian Mountain Range (Iván et al., 2011), the Tihany Peninsula in Lake Balaton (Tóth et al., 2017) and the Gömör-Torna karst region on the Slovakian-Hungarian border (Iván \& MádlSzőnyi, 2019), but is missing for the Mecsek Karst area in southwestern Hungary (Figure 1).

Fundamentally the objectives of our study were threefold. The eight initial principal catchment areas were delineated using tracer tests in the early 1970s. However, the boundaries were determined with a high level of uncertainty (Rónaki, 1973). Therefore, our first aim was to refine the boundaries of the catchment areas for a karst aquifer through the analysis of geological and topographical features. Secondly, we aimed to generate vulnerability and risk maps of the Mecsek Karst, using two methods, the COP (flow Concentration, Overlaying layers and

Precipitation) and the SA (Slovene Approach) in GIS environment on a highly variegated Mecsek Karst aquifer. Our third aim was to validate the vulnerability maps based on the former tracer tests and to determine the main protection zones. 


\section{GEOGRAPHICAL AND GEOLOGICAL SETTING}

The Mecsek karst is located in SW Hungary and encompasses an area of about $30 \mathrm{~km}^{2}$ (Figure 1). It is a hilly area with relatively high relief and altitudes ranging from 200 to about $600 \mathrm{~m}$ a.m.s.l. The study area lies in the temperate zone and is characterized by moderate continental climate (Péczely, 2009), with a mean annual precipitation of 700 to $800 \mathrm{~mm}$ (Bötkös, 2006). Although the area is a nature reserve, still, human interventions are not negligible as multiple infrastructural facilities, buildings, roads and a zoo are found in the area which are all poses possible threats to groundwater quality.

The karst system, geologically, is part of the Western Mecsek northward/eastward dipping perianticline (Figure 1). The crystalline basement consists of Early $\mathrm{Pa}-$ leozoic - Early Carboniferous granite, migmatite, phyllite and serpentinite which may function as aquitards (Fülöp, 1994). Continental clastic sedimentation started in the Late Carboniferous and lasted until the Early Triassic (Jámbor, 1969; Barabás-Stuhl, 1988). Permian layers are mostly sandstones, siltstones, claystones and dominantly function as aquitards while the Lower-Middle Triassic sandstone has relatively large hydraulic conductivity values (Table 1). These layers are overlain by siltstone and dolomite (Vozárová et al., 2009). From a hydrogeological viewpoint, these layers form an impermeable barrier that forms a boundary between the Lower-Triassic uraniumbearing sandstone and the Middle Triassic carbonate rocks (Figure 2A; Table 1). This limestone is characterized by multiple karstic features like dolines and sinkholes and stores an economically significant karst water supply. It is overlain by Late Triassic - Early Cretaceous formations (at first marl and strongly cemented sandstone, overlain by coal seams and finally by pelagic sediments mixed with basalt). These formations are almost impermeable (low permeability) therefore water does not infiltrate here from the overlying strata. The Permian Mesozoic succession is overlain by Miocene aquifer-like sediments after an unconformity (Figure 1; Table 1). The

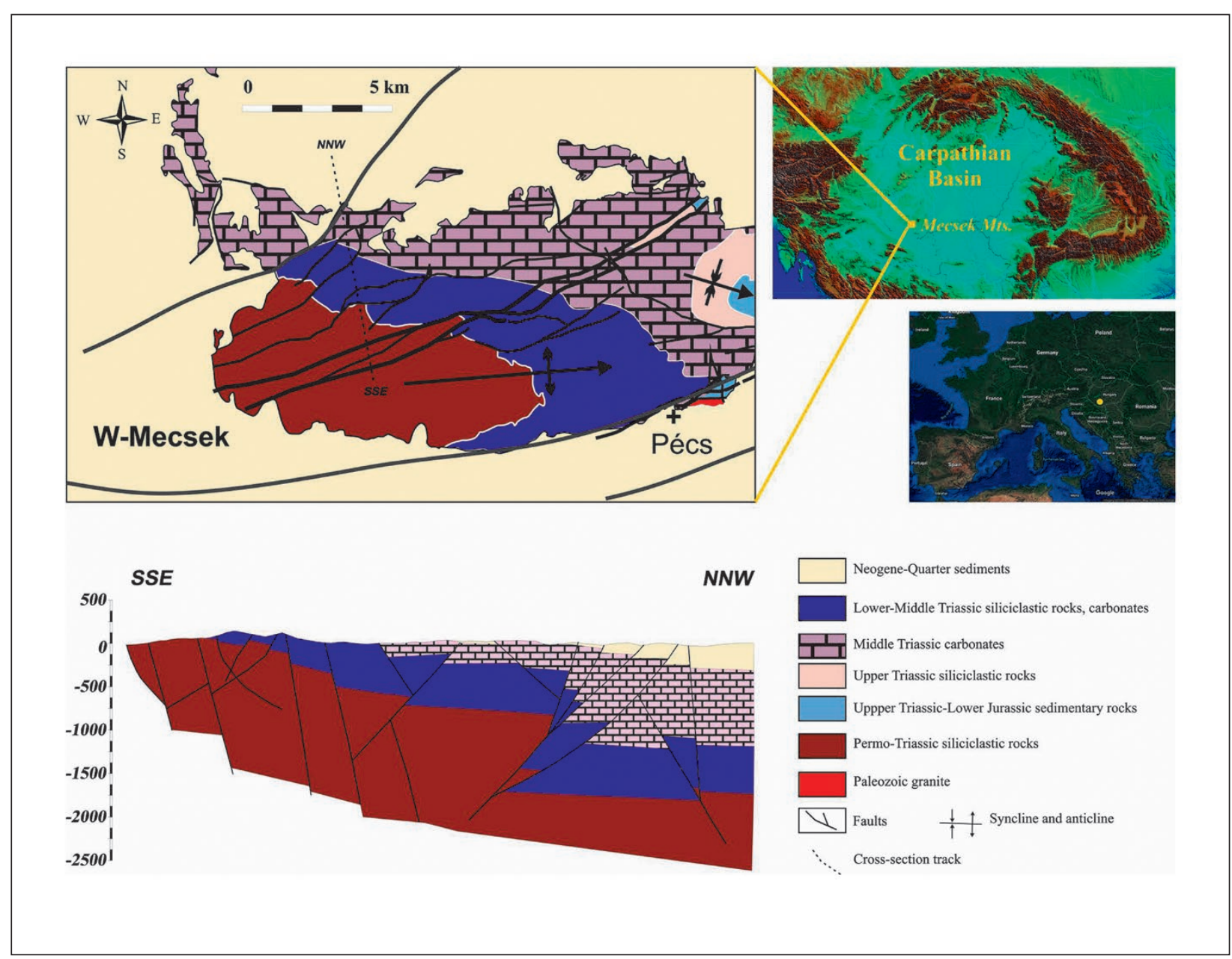

Figure 1: Geological settings of the Mecsek karst area. Fractured zones can be followed along the fault zones (Konrád et al., 2010). 
prevailing diagnostic soil types of the area, according to the WRB classification, are Haplic Luvisols and Rendzinas. The dominant vegetation is deciduous forests with the dominance of European beech (Fagus sylvatica) and European hornbeam (Carpinus betulus) (Hoyk, 2001; Morschhauser \& Salamon-Albert, 2001).

Table 1: Hydraulic conductivity values of various rock types of the studied area (Rónaki, 1973).

\begin{tabular}{|c|c|c|c|}
\hline \multirow{2}{*}{\multicolumn{2}{|c|}{ Rock types }} & \multicolumn{2}{|c|}{$\begin{array}{l}\text { Hydraulic conductivity } \\
(\mathrm{m} / \mathrm{s})\end{array}$} \\
\hline & & Fragmented & Unfragmented \\
\hline \multicolumn{2}{|c|}{ Neogene sediments } & - & $10^{-9}-10^{-4}$ \\
\hline \multicolumn{2}{|c|}{ Middle Triassic carbonates } & $>10^{-4}$ & $<10^{-9}$ \\
\hline \multicolumn{2}{|c|}{$\begin{array}{l}\text { Lower-Middle Triassic } \\
\text { carbonates }\end{array}$} & $10^{-7}-10^{-4}$ & $10-11-10-7$ \\
\hline \multirow{3}{*}{$\begin{array}{l}\text { Permo-Triassic } \\
\text { siliciclastic rocks }\end{array}$} & siltstone & $10^{-6}-10^{-4}$ & $10-10-10-8$ \\
\hline & sandstone & $10^{-7}-10^{-3}$ & $10-11-10-4$ \\
\hline & claystone & $10^{-9}-10^{-7}$ & $10-14-10-9$ \\
\hline
\end{tabular}

The studied aquifer was divided into eight individual catchments by Rónaki (1973), namely the Paplika, Kispaplika, Mészégető, Vízfö, Gyula, Kánya, Anyák kútja and Tettye watersheds (Figure 2), of which the Tettye Catchment supplies drinking water for Pécs, the fifth most populous (ca. 140,000 residents) city in Hungary. However, owing to the low resolution of the employed topographic maps available in the 1970s, and the relatively few tracer tests, it was indispensable to refine the catchment boundaries with GIS-based digital elevation models for the analyses performed during the current research.
In most of the area topography determines the natural borders of the karst, except for the areas where petrological properties constrain water dynamics (e.g. at Tettye Catchment on the west, north and east). At the southern border of the Tettye Catchment a thrust fault, dipping to the north, is found above an aquitard-like sequence (Figure 1; Konrád \& Sebe, 2010). Within the karst aquifer the subsurface catchments were separated by tracer tests (Rónaki, 1973).

The catchments are mostly autogenic karsts, made up of solely carbonate-rich rocks (Figure 2A). Re-supply of groundwater in the area is dominated by point infiltration via sinkholes and dolines. There are well-developed cave systems in the areas: their presence has been proven by extensive tracer tests (Rónaki, 1973). Due to structural evolution of the Western Mecsek since the Late Miocene, there is an approximately $\mathrm{E}-\mathrm{W}$-oriented compression and hence a N-Soriented extension in the area (Csontos et al., 2002). Therefore, presumably, the N-S oriented extension predetermined the main direction of the subsurface passage (Bauer \& M. Tóth, 2015). Where sinkholes and subsurface passageways are scarce or completely absent, diffuse infiltration dominates the replenishment of the aquifer. The Catchments of the Vizfó, Paplika and Gyula Springs are considered as allogenic karsts, where, in addition to carbonate rocks, sandstone, siltstone and evaporates, characterized by low hydraulic conductivities, are also present (Figure 2A). The groundwater of the allogenic karst area is recharged by losing streams that convey water from non-karstic regions (Figure 3). Based on the prevailing hydrogeological conditions of the area, discharge from the unconfined karst aquifer occur along

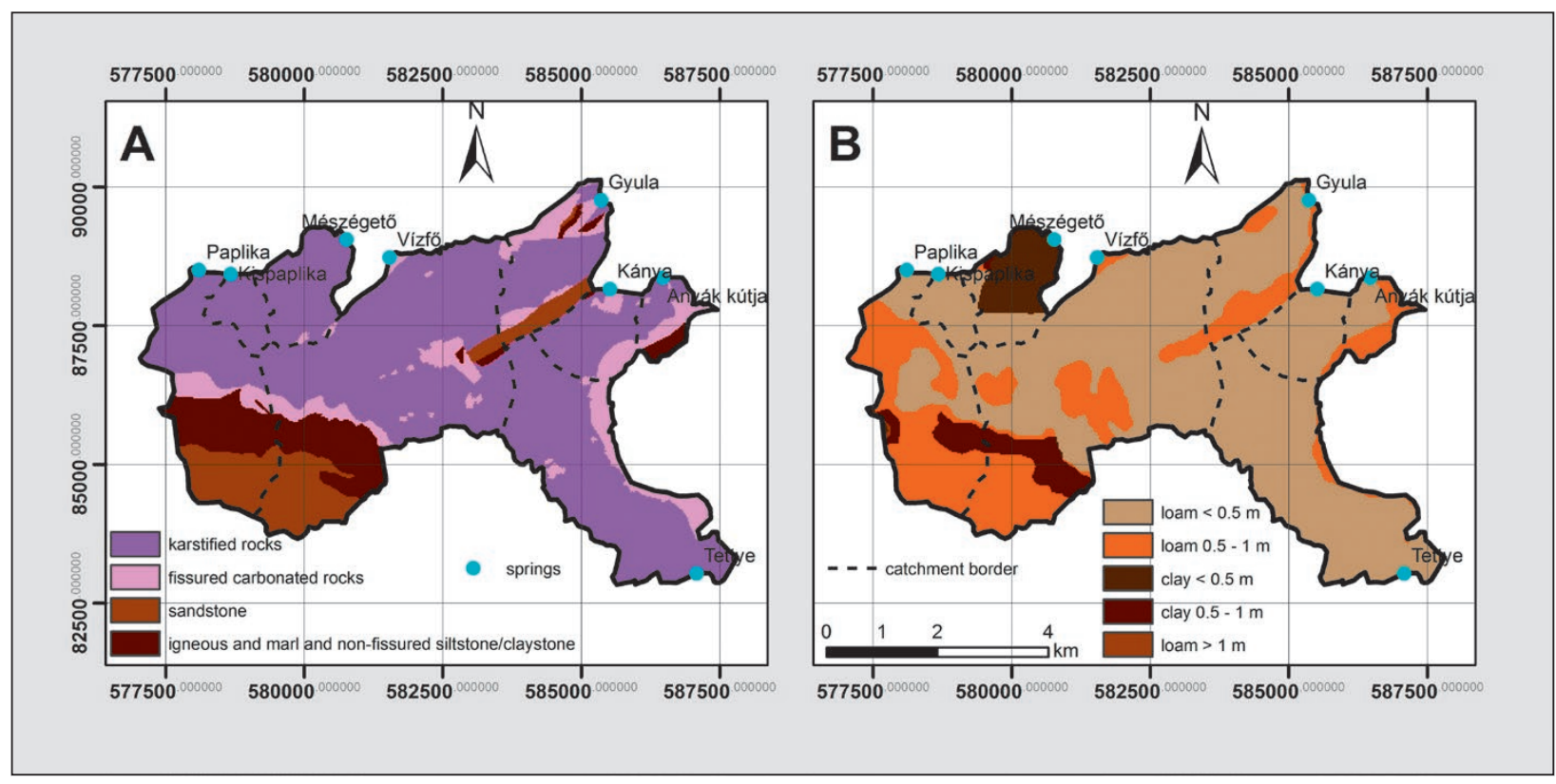

Figure 2: A) Lithology map of the study area without Quaternary loess; B) Texture and thickness of the soil in the study area. 
its northern border (Rónaki, 1973, 2007). Further north the karst aquifer becomes confined under steadily deepening Miocene sequences (Figure 1). The karst water table elevations gradually decrease from the south (about $260-280 \mathrm{~m})$ to the north (220-230 m). The Tettye Catch- ment is an exception where the karst water table elevation is the highest at its northern border (about 300-310 $\mathrm{m}$ ) and discharges groundwater at its southern edge (Tettye Spring at $233 \mathrm{~m}$ ).

\section{METHODS}

A significant degree of uncertainty was involved in the catchment boundary delineation performed by Rónaki (1973). This was due to the low resolution topographic maps available at that time, as well as the low number of tracer tests performed in the studied area. Therefore, firstly, we refined the boundaries of the studied catchments in ArcGIS software environment. For catchment delineation a detailed 1:25,000 geology map (Chikán et al., 1984) was georeferenced in EOV (Egységes Országos Vetületi rendszer, in English: Unified National Projection System) coordinate system. Some borders were defined by topographic features, where the borders were identified by using the r.watershed GRASS tool on the 1:25,000 Digital Elevation Model (DEM), while other boundaries were defined based on geological settings. Data of former tracer tests (Rónaki, 2007) were also integrated into the delineation of the catchments.

\section{RESOURCE VULNERABILTY MAP}

The 1:25,000 resource vulnerability and risk intensity maps were generated in qGIS 3.10 with GRASS 7.8 and ArcMap 10.7 programs. Two approaches for resource vulnerability mapping were applied to assess the vulnerability to pollution for this work: (i) the COP method (Vías et al., 2006) and (ii) the Slovene Approach (Ravbar \& Goldscheider, 2007). Both methods include three major factors to determine vulnerability, namely (i) flow concentration (C), (ii) overlaying layers $(\mathrm{O})$ and (iii) precipitation $(\mathrm{P})$. The Slovene Approach is partly based on COP method, but was specifically adapted to Slovene karstic environments (Ravbar \& Goldscheider, 2007).

The $\mathrm{O}$ factor indicates the filtration efficiency of the overlying layers above the zone of saturation (Daly et al., 2002). It takes into account the residence time of the percolating water (and/or contaminant) through the medium of the unsaturated zone. It is further subdivided into two sub-factors, namely soils (Os factor) and lithological layers (Ol factor). For soil mapping, the DOSoReMI digital soil map of 1:25,000 resolution was used which contained spatial data on soil depth and soil texture for every $30 \mathrm{~cm}$ depth intervals (Laborczi et al., 2016, 2018). Lithology was assessed based on the dominant rock type (ly) of the study area, the confined or unconfined character of the aquifer ( $\mathrm{cn}$ ) and the depth of the unsaturated zone (m). A lithological map of 1:25,000 resolution showing the bedrocks without the overlying Quaternary sediments, was employed in the generation of the vulnerability model (Chikán et al., 1984). The confinement of the aquifer, i.e. the spatial distribution of the Quaternary sediments, was determined based on a field-surveyed map at a resolution of 1:10,000 (Chikán \& Budai eds., 2005). The depth of the unsaturated zone was calculated according to the hydraulic head values, which were available in Csurgó \& Szulimán (2017).

A karst aquifer is characterized by diffuse and concentrated infiltration processes. If many sinkholes are found in the area, then they function as preferential flow paths and the majority of the water is conveyed through them, therefore avoiding Darcyan flow in the vadose zone. In this case factor $\mathrm{C}$ is calculated based on the distance to sinkholes (dh) and losing streams (ds), as well as the slope (sl) and the vegetation (vc), separately. The latter two parameters are considered in recent study as two independent factors from each other. Hence, the SA and COP methods were a little modified in this study. The locations of the sinkholes and dolines in the Mecsek karst area were defined based on Rónaki's (1973) map and on the 1:25,000 DEM (Figure 3). Distances to each sinkhole and doline (dh) as well as from losing streams (ds) were calculated using raster-based Euclidean distance tools. The slope map was derived from the 1:25,000 DEM. The vegetation cover was determined according to Hoyk (2001) and Morschhauser \& Salamon-Albert (2001). The SA method also accounts for the permeability of the surface layers which was determined based on the soil and lithology maps.

The $\mathrm{P}$ factor refers to the influence of precipitation. It is subdivided into two sub-factors: quantity of precipitation (PQ) and temporal distribution of precipitation (PI) in the COP method. At the SA method the P factor is defined by the following two parameters: (i) the number of rainy days (rd) and (ii) the number of annual storm events (se). The relevant meteorological data was obtained from the Hungarian Meteorological Services 
for the weather stations in Pogány (2007-2019) and at the Ifjúság Street campus of University of Pécs (2008-2019).

\section{HAZARD MAP GENERATION}

Hazard mapping is a suitable tool to identify and visualize the locations and types of human interventions that may threat groundwater quality. Hazard levels were defined by quantifying the three main influencing factors, weighting, ranking and reduction values (Ravbar \& Goldscheider, 2007; Figure 4). The weighting factor (H) accounts for toxicity, solubility and mobility of the contaminants. Their values ranged between 10 and 100, as it is shown in the Final Report COST Action 620, p. 95-96. The ranking factor $(Q n)$ ranks the source of con- taminants, on a scale between 0.8 and 1.2. The reduction factor $(R f)$ expresses the probability of a contamination event to occur, with its values ranging between 0 and 1 . When it is 1 , then no information is available on contamination likelihood.

\section{RISK INTENSITY MAP GENERATION}

Following its generation, the hazard map of the studied area was combined with the two resource vulnerability maps (the SA and the COP methods, respectively) generating the two risk intensity maps that combined both natural and anthropogenic factors on vulnerability assessment (Figure 4).

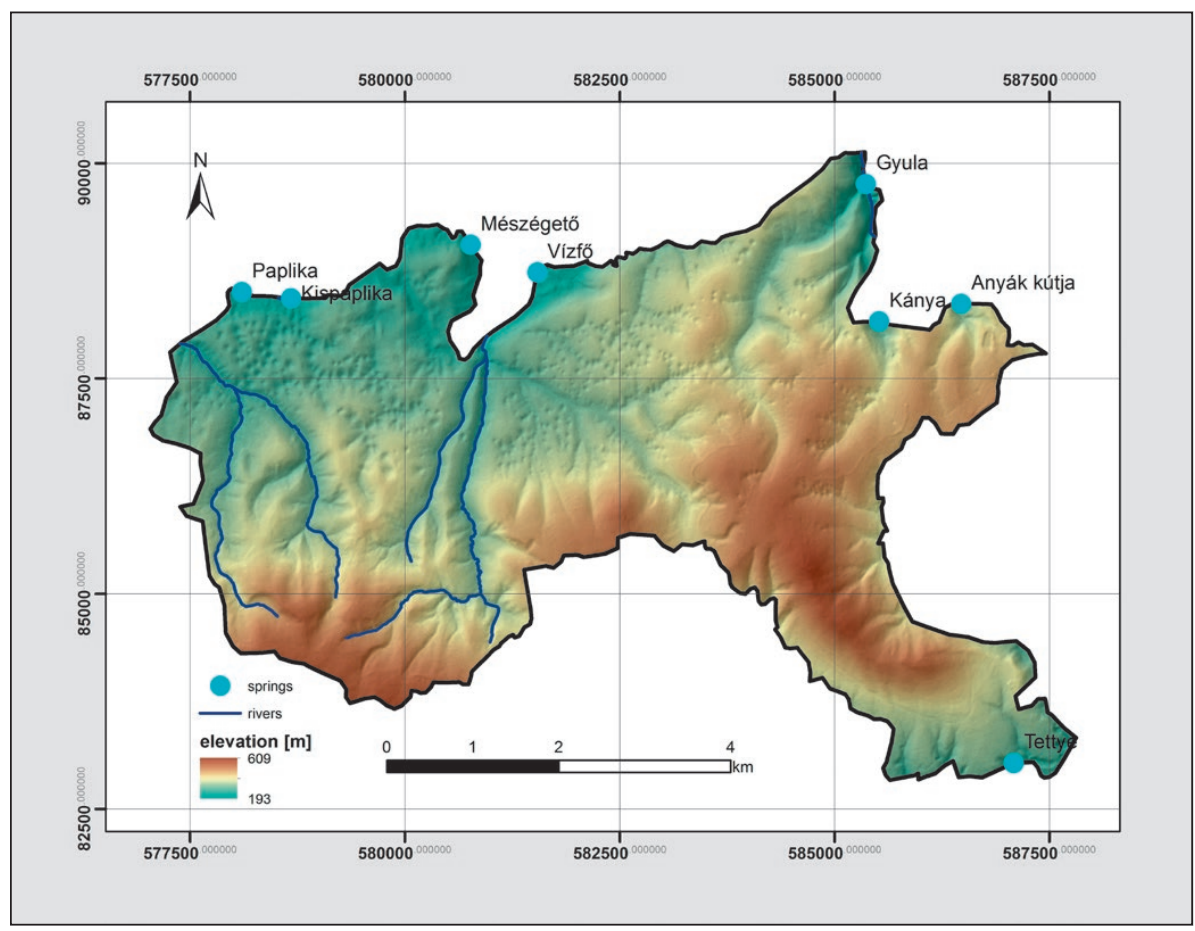

Figure 3: Locations of sinkholes/ dolines and losing streams in the Mecsek Karst area (based on 1:25,000 Digital Elevation Model).

\section{HAZARD}

Hazard score $=\mathrm{H}^{*} \mathbf{Q} \mathbf{n} * \mathbf{R f}$

\begin{tabular}{|c|c|c|}
\hline Hazard score & Hazard index & Hazard level \\
\hline 0 & 5 & No hazard \\
\hline$(0-24]$ & 4 & Very low \\
\hline$(24-48]$ & 3 & Low \\
\hline$(48-72]$ & 2 & Moderate \\
\hline (72 - 96] & 1 & High \\
\hline$(96-120]$ & 0 & Extreme \\
\hline
\end{tabular}

\section{RISK INTENSITY}

Risk intensity $=$ Resource index + Hazard index

\begin{tabular}{|c|c|c|c|}
\hline $\begin{array}{c}\text { Risk } \\
\text { intensity }\end{array}$ & $\begin{array}{c}\text { Risk intensity } \\
\text { index }\end{array}$ & $\begin{array}{c}\text { Risk intensity } \\
\text { level }\end{array}$ & \multirow{4}{*}{ 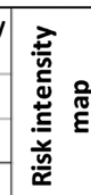 } \\
\hline $1-4$ & 2 & High & \\
\hline $5-6$ & 1 & Moderate & \\
\hline$\geq 7$ & 0 & Low & \\
\hline
\end{tabular}

Figure 4: Hazard level and contamination risk assessment categories (after Ravbar \& Goldscheider, 2007). 


\section{RESULTS AND DISCUSSION}

\section{INTRINSIC VULNERABILITY MAPPING (RESOURCE VULNERABILITY MAP)}

Eight catchments were delineated in the study site. The SA-based COP indices of the Mecsek karst area were grouped into five vulnerability classes (very low, low, moderate, high and extreme), while for the COP method only three categories (moderate, high and extreme) were used.

Low COP scores $(<1)$ indicate the most vulnerable areas, where protection values of $\mathrm{O}$ score are low (Figure $5 \mathrm{~A}, \mathrm{~B}$; Figure 6A, B), because strongly karstified carbonate rock outcrops are found (Figure $2 \mathrm{~A}$ ), i.e. soil cover is either absent $(<0.2 \mathrm{~m})$ or thin $(<0.5 \mathrm{~m})$ or as a secondary criteria texture is mostly loamy or clayey $(>30 \%$ clay content) (Figure 2B). These areas have a negligible mitigation of protection based on C score (Figure 5C, D). These areas are characterized by a large number of sinkholes enhancing the rapid conveyance of water to the aquifer. Therefore, vulnerability decreases with increasing distance from the sinkholes. Topography plays a relatively minor role on contamination hazard compared to the influence exerted by sinkholes, but in selected regions it may contribute to increased runoff like in the southwestern margin of the Tettye Catchment where slopes exceed $31 \%$. In the latter region surface runoff prevails and adsorption of contaminants by clay minerals and organic matter is limited. In addition, highly vulnerable zones (COP score $<1$ ) are also found at and around losing streams (Figure 5C, D; Figure 6A, B). Such water bodies are particularly frequent in the southwestern hilly part of the study site, where sandstone, siltstone and evaporites are found on the surface and streams disappear into the sinkholes rapidly as they reach the border with the karstic rocks (Figure 5D). Based on our results, regions of extreme vulnerability cover larger areas in the COP method than in the SA method (Figure 6A, B).

Moderate vulnerability (1-2 COP score) in SA method indicates zones (Figure 6B) where carbonate outcrops are found, however they are usually located at a relatively great distance from the sinkholes (autogenic karsts with karst pavements and barren carbonates). Here infiltration along fractures, fissures, cleavage surfaces and pas-

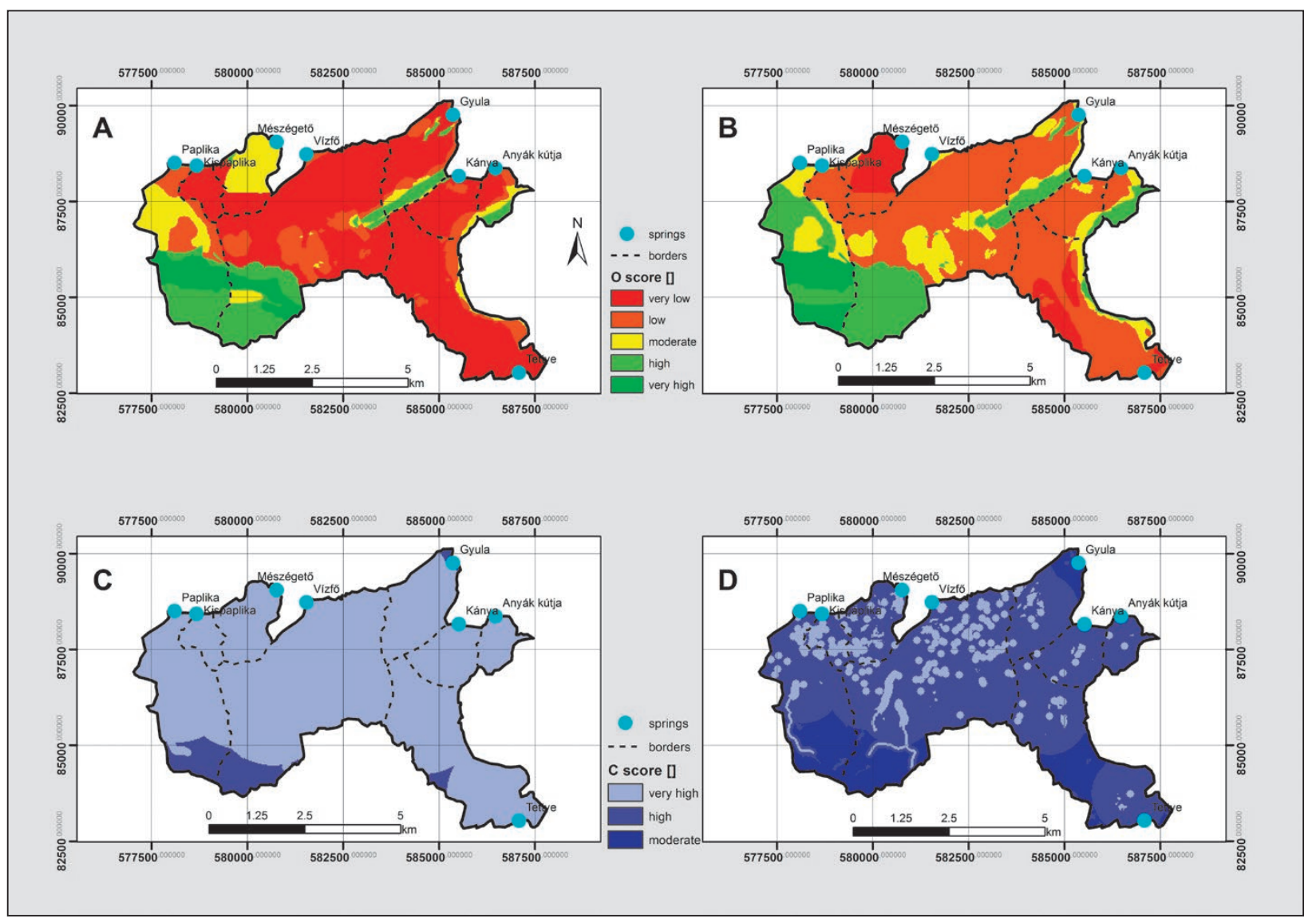

Figure 5: Map of O score based on A) COP; B) and map of C score C) COP; D) in the study area. 
sage ways is the dominant recharge process. Similarly to the zone of highest vulnerability, adsorption of contaminants by soils is almost negligible here, as Rendzina soils are dominantly characterized by shallow depths of $<0.5$ $\mathrm{m}$. In general, these areas are relatively flat with the absence of steep slopes.

Principally in the southern part of the Paplika, Vízfö and Gyula Catchment the COP score is high (2-15) indicating low and very low vulnerability in SA method and moderate/low vulnerability in COP method (Figure 6A, B). These areas correspond to (i) autogenic karst with soil covers exceeding 0.5 meters and (ii) allogenic karsts of aquitard-like sediments and sedimentary rocks (sandstones, igneous rocks, claystones, siltstones and evaporites). The latter areas are covered by soils of more than 0.5 -meter depth with loamy and clayey ( $>30 \%$ clay content) texture. The lowest vulnerability was found in the Paplika Catchment where discontinuous loess sediments overlay the carbonate rocks (Figure 2).

The $\mathrm{P}$ score does not show large variability within the studied area. The annual number of days without rain is about 240-250 days per year. This values of annual rainy days correspond with a $\mathrm{P}$ factor of 0.9 ac- cording to the COP method. The P factor is 1 by the SA method homogeneously within the study site. However, the SA method also accounts for the annual number of days when daily precipitation totals between 20 and 80 , and exceeds $80 \mathrm{~mm}$ per day (stormy days). The number of days with precipitation totals between 20 and $80 \mathrm{~mm}$ averaged 7.55 and 7.15 days per year for the University of Pécs and Pogány stations, respectively. Daily precipitation of more than $80 \mathrm{~mm}$ was observed two times at the university and only once in Pogány over the studied periods.

\section{SPATIAL DIFFERENCES BETWEEN THE MAPS OF THE SA AND COP METHODS}

Despite the similarities, the COP and the SA resource vulnerability maps show some important differences. It shall be pointed out, however, that we did not consider on the differences in vulnerability indexing categorization, but we simply calculated the differences in the actual pixel values between the two methods. Differences were dominantly negative which principally indicates higher vulnerability values for the COP map as the pixel values of the COP map was subtracted from those of the

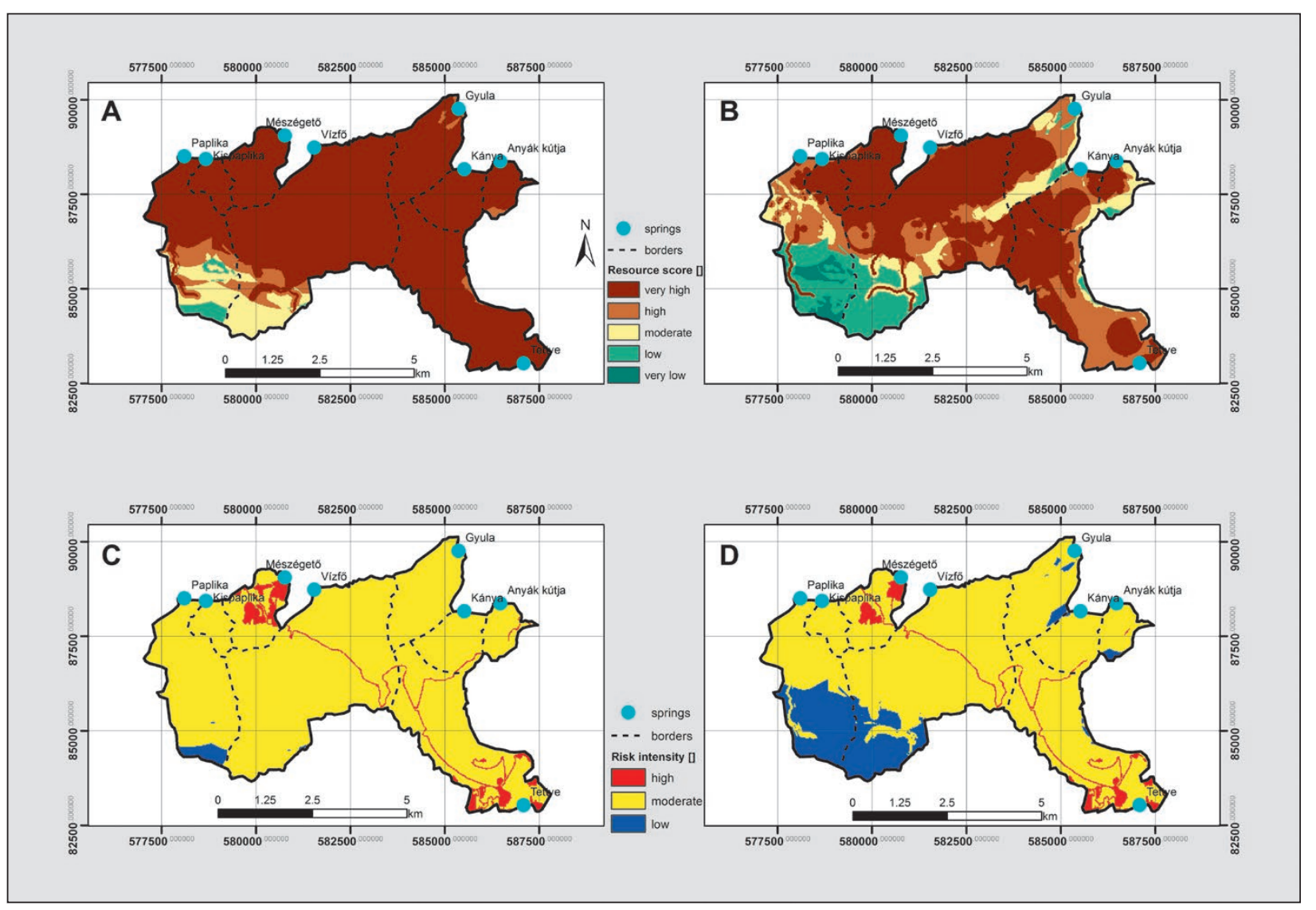

Figure 6: Spatial distribution of Resource vulnerability map scores based on A) COP; B) SA and risk intensities based on C) COP; D) SA in the study area. 
SA map. The most negative differences were observed in the southwestern section and the central-eastern portion along of the area (Figure 7). These two areas are dominated by sandstone, siltstone and evaporites of low permeability and deeper soil covers (Figure 2).

Positive differences (SA - COP) were only found in the Catchment of the Mészégetö Spring (Figure 7). Therefore, the COP mapping method indicated higher (extreme) vulnerability for nearly the entire studied area (Figure 6A). The positive differences in the catchment of the Mészégető Spring is likely attributed to the different indexing algorithm between the COP and SA maps as clayey soils are considered impermeable in the COP, therefore an index value of 5 is assigned to this soil. On the other hand, clay-rich soils have a vulnerability index of only 2 in the SA method (Ravbar \& Goldscheider, 2007).

\section{VALIDATION OF THE RESOURCE VULNERABILITY MAP}

Validation of the vulnerability maps was done using hydrodynamic tracer response data obtained by Goldscheider et al. (2001) and Rónaki (2007). The latter dataset, however, only included the location of the injection sites, the detection points and the corresponding flow velocity values. For this reason, the calculation of the transit times was necessary in GIS environment from the given flow velocity and distance data. The latter was measured as a straight line between the point of injection and the associated spring. However, this approach is likely bur- dened by errors as subsurface passage ways are not necessarily straight therefore transit times are likely slightly underestimated by this method. The points of injection were located near to or identical with the locations of the sinkholes. Transit times averaged 5 to 10 days, only a few tracer tests had transit times of more than 20 days (Figure 8). In general, these principally short transit times correspond with extreme vulnerability values (Jeannin et al., 2001). In general, a transit times were characterized by a large variability, however the majority of the observed travel times were shorter than 10 days. Longer than 10 days were only observed in 7 sinkholes. Generally, shorter travel times were found in the northern part of the Mecsek Karst area. The two shortest times were found in the catchment of the Gyula Spring (1.407 days) and the Tettye Spring ( 0.9 days). The Tettye Catchment (one of the drinking water suppliers of the city of Pécs) had the longest travel times and the largest temporal variability, with a peculiar extreme of 0.9 and 32.75 days detected in the same sinkhole in the zoo. Rónaki (2007) approved the shorter time and considered the longer one as a result of clogging of subsurface conduits. In contrast, however, a transit time of 37.25 days was also measured in the extreme SE tip of the Tettye Catchment which corroborates the rationality of the transit time of 32 days measured in the sinkhole located in the zoo. Nonetheless, in the NW segment of the Tettye Catchment, transit times increased to 22 to 25 days. The Vízfó catchment had rather uniform transit times (2.54 to 9 days) with one exception of 21.318 days in the NE corner of the catchment.

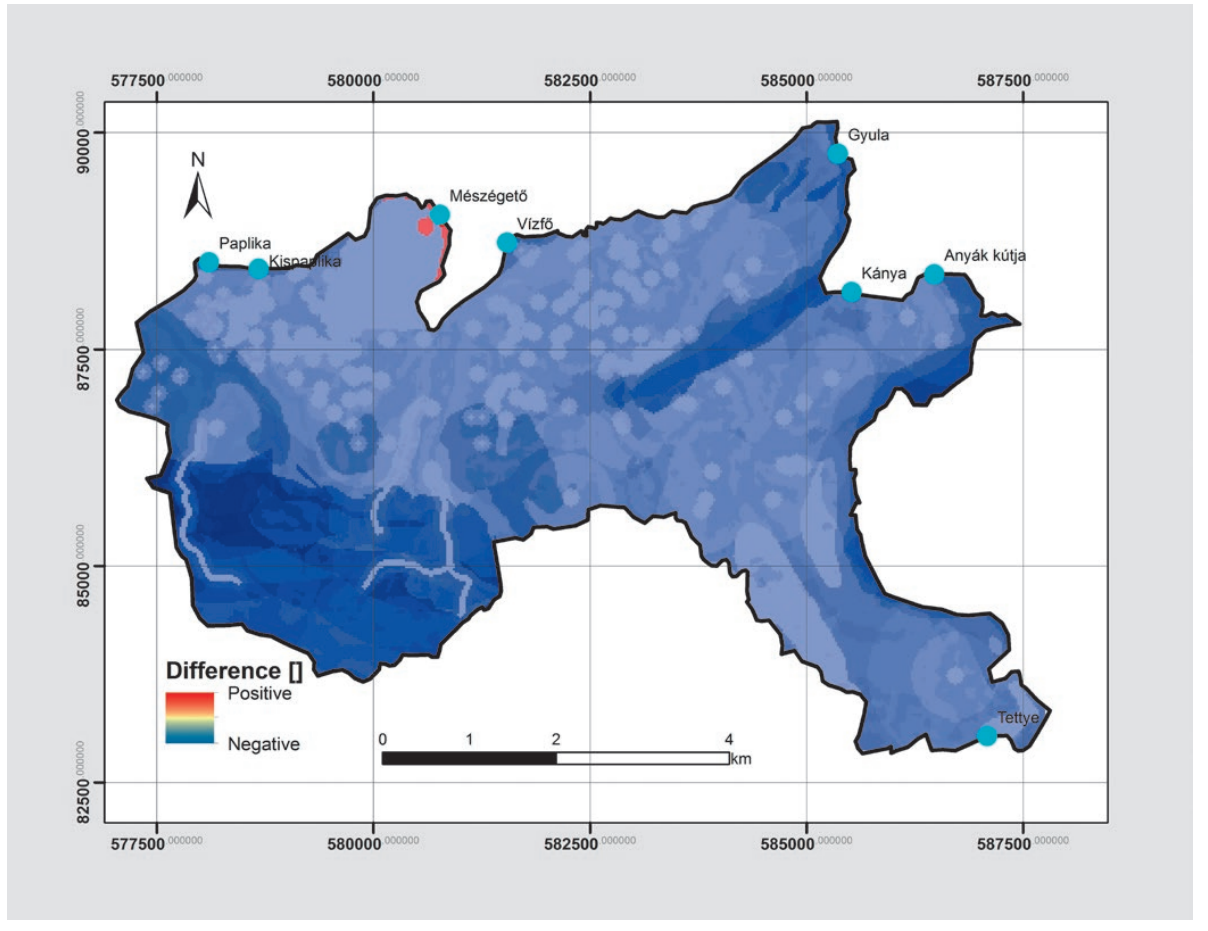

Figure 7: Pixel-based spatial differences $(S A-C O P)$ between the COP and the SA resource vulnerability maps. Map was generated by subtracting the COP map from the SA map. 


\section{HAZARDS}

The hazard sources, based on the EU COST action 620, are showed in the Table 2. According to the spatial distribution of potential contamination sources, the Mecsek karst area can be divided into two principal regions. The Tettye (partly located under the city of Pécs) region in the southeast is more densely populated (about 60 residents/ $\mathrm{km}^{2}$ ), while the northwestern Orfü region is character- ized by a population density of less than 60 residents per $\mathrm{km}^{2}$ (Figure 9).

Properties at both areas are connected to the public sewage system and the wastewater treatment plant located outside the karst area. Agricultural activity is low in the Orfü area, only an equestrian farm with pastures and some small plow lands are found here. Highway 6604, which connects the village of Orfü and the city of Pécs,
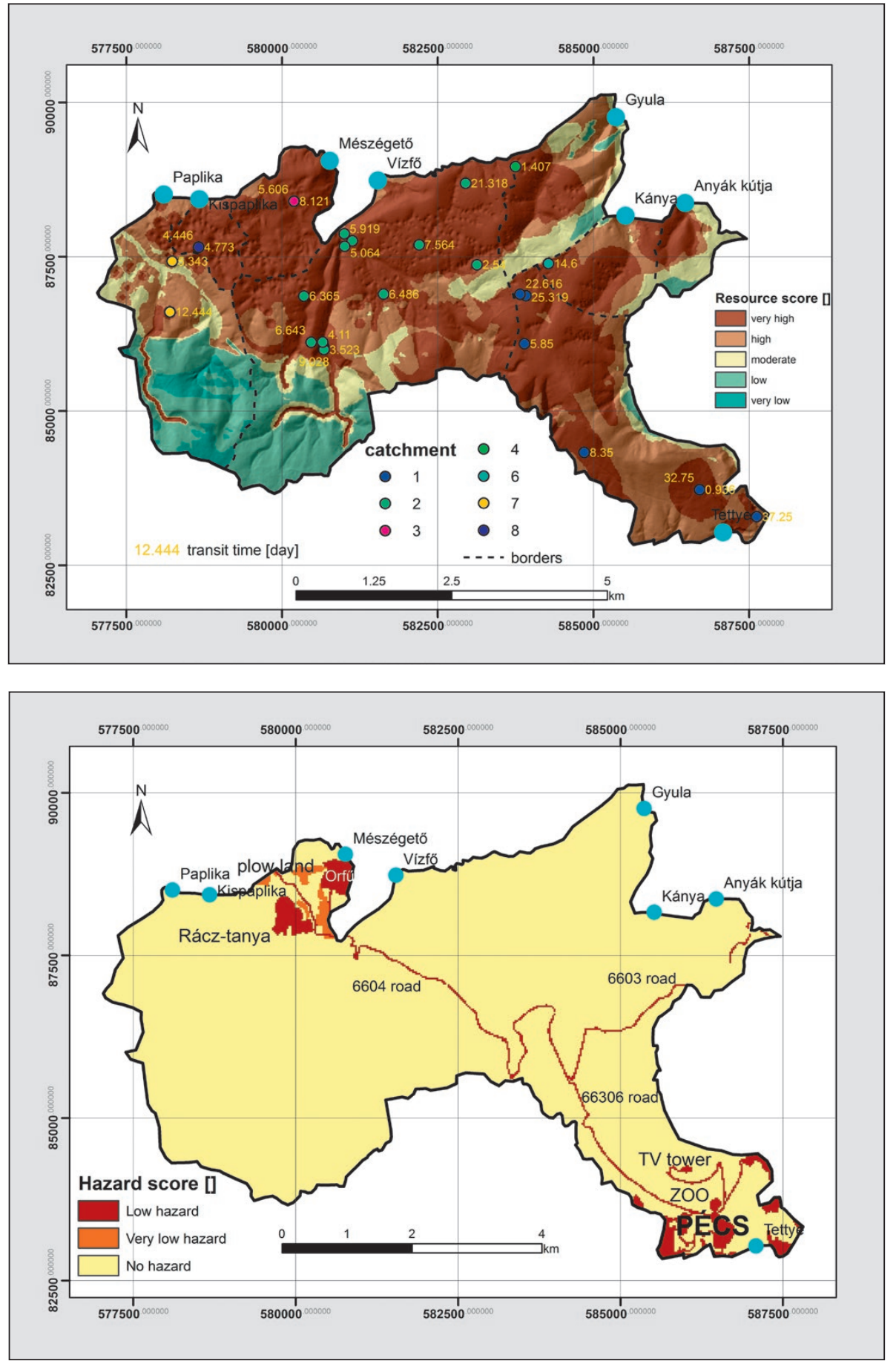

Figure 8: Validation of SA resource vulnerability map with former tracer tests (data from Rónaki, 2007).

Figure 9: Hazard map of the Mecsek Karst. 
Table 2: Hazard ranking.

\begin{tabular}{|l|c|c|c|c|c|c|c|}
\hline Hazards & $\begin{array}{c}\text { Weighting } \\
\text { value (H) }\end{array}$ & $\begin{array}{c}\text { Classification } \\
\text { criteria }\end{array}$ & \multicolumn{5}{|c|}{ Ranking factor (Qn) } \\
\hline Infrastructural development & & & $\mathbf{0 . 8}$ & $\mathbf{0 . 9}$ & 1 & 1.1 & 1.2 \\
\hline Waste water (urbanisation) & 35 & $\begin{array}{c}\text { Population densitiy } \\
\text { (inhabitant/km²) }\end{array}$ & $<10$ & {$[10-50)$} & {$[50-100)$} & {$[100-500)$} & $\geq 500$ \\
\hline Transport and traffic, roads & 40 & No. Vehicles/day & $\begin{array}{c}< \\
100\end{array}$ & {$[100-1000)$} & {$[1000-5000)$} & {$[5000-10000)$} & $\geq 10000$ \\
\hline Recreational facilities & 30 & No. Visitors/day & $<10$ & {$[10-100)$} & {$[100-500)$} & {$[500-1000)$} & $\geq 1000$ \\
\hline
\end{tabular}

has a relatively heavy traffic, however, besides this, only minor rural roads of low traffic are found in the karst area. A few recreational facilities also operate in the area, including a TV tower and a zoo. However, on more than $80 \%$ of the entire area no potential hazard sources were identified (Figure 9).

\section{EVALUATION OF CONTAMINATION RISK INTENSITY}

When the hazard map was combined with the two resource vulnerability maps (called risk map hereafter), a completely different picture of risk potential was obtained which embraced both natural and human influences on karst risk to pollution (Figure 6C, D). The highest risk in the SA map was associated with areas of high population densities in southeastern portion of the area (Pécs) and in and around the village of Orfü. Roads also posed a relatively large threat to the aquifer as heavy rainfalls wash off contamination deposited on paved surfaces. The southwestern portion of the area had the lowest risk due to the low permeability values of the silt- and sandstone rocks and the limited human influences. Areas of low risk intensity covered a smaller area in the COP map due to the differences in intrinsic vulnerability classification of the two resource vulnerability maps. The main differences were observed in the SW section and small areas in the eastern and northeastern areas (Figure 6C, D).

\section{A NEW PROTOCOL FOR THE DELINEATION OF THE MECSEK KARST PROTECTION ZONES}

Protection of karst water springs requires the detailed analysis of environmental factors including analysis of hydrogeological properties and water dynamics, assessment of the vulnerability of the spring to contamination, validation of the vulnerability mapping and their implementation in practical planning. To ease future vulnerability mapping protocols of relatively small and divers karstic areas in the humid temperate zone, a new protocol has been elaborated for the delineation of protection zones over the course of the current study.

\section{COMPARATIVE ANALYSIS OF THE TWO RISK VULNERABILITY MAPS}

Multiple methods exist on vulnerability mapping of karst areas. Hitherto, however, only a few studies attempted the comparison of various vulnerability mapping methods (e.g. Goldscheider, 2005; Ravbar \& Goldscheider, 2009; Marín et al., 2015).

According to our findings the SA map had a higher resolution and was more detailed than the COP map and showed a more detailed picture of the studied area. Pre- viously, the Slovene Approach has been predominantly used for lithologically and pedologically diverse areas of few $10 \mathrm{~km}^{2}$ (Ravbar \& Goldscheider, 2009), whereas the COP method was primarily applied for relatively large and more homogeneous areas (Vías et al., 2006; Andreo et al., 2009). Our results also corroborated the latter conclusions, i.e. the SA method outperformed the COP method in terms of vulnerability mapping resolution and accuracy for a relatively small and spatially varied karstic aquifer. Similarly, to our findings, the results of Ravbar \& Goldscheider (2009) demonstrated that the Simplified Method of COP overestimates vulnerability, while the Slovene Approach tends to deliver more realistic results. According to Marín et al. (2014) the main differences between the two methods stems from the fact that the vulnerability classes of the $\mathrm{COP}+\mathrm{K}$ method are mainly influenced by infiltration conditions and the distances to water source. The vulnerability classes of the Slovene Approach mainly depend on soil depth, the presence of morphological features and the temporal hydrological variability (Marín et al., 2014). 


\section{DELINEATION OF THE PROTECTION ZONES}

Hitherto, similarly to the main objectives of the current study, a large number of papers have applied successfully the vulnerability map concept for the delineation of protection zones in other karst areas similar, in terms of topography, climate and vegetation, to the Mecsek Karst (e.g. Marín et al., 2015; Turpaud et al., 2018; Jakada et al., 2019). During the present study we delineated the main protection zones of the Mecsek Karst aquifer and generated vulnerability maps in conjunction with the transit time data from archive tracer tests. It needs to be pointed out, however, that the currently proposed zonation is not novel. Here, the novelty is that the already existing general, travel time-based vulnerability categories were applied for karstic areas. As an outcome, the following protection zones are proposed for the karstic portions of the Mecsek Hills based on Figure 8:

(i) Zone I, which requires the highest level of protection. It coincides with areas of extreme resource vulnerability (sinkholes and losing stream catchments, karst features with high infiltration capacity). Called internal hydrogeological zones in the Hungarian legislative terminology.

(ii) Zone II, areas that require high protection, represents the areas of high resource vulnerability (sinkholes and losing streams are located farther away of catchment areas, noncovered (autogenic) karsts without overlying soil, sediment or rock layers - e.g. in the central part of the Tettye Catchment, Mészégető Catchment).

(iii) Zone III, in general, are sectors with moderate resource vulnerability. Moderate vulnerability has been assigned to barren karst landscapes of less karstified limestone or dolomite.

(iv) Zones IV and V are non-karstic areas requiring a low or very low degree of protection.

In Hungary the protection zones are defined based on the transit times from the point of infiltration to the corresponding spring as follows: internal (less than 20 days), external (less than 180 day), hydrogeological A (less than 5 years) and hydrogeological B (less than 50 years) zones (123/1997 VII.18, Government Regulation). In general, more sophisticated zonation procedure is required in the Mecsek Karst area. For instance, the NW Tettye Catchment, based on the transit times belongs to Zone 2 (with transit times exceeding 20 days). However, the contrasting transit times were found in its SE tip of the Tettye Catchment: this spatial contradiction is resolved and smoothed by the resource vulnerability map. Secondly, the COP is too "strict" in the zonation of the hazard zones, as almost the entire study area belongs to the zone of the highest protection (extreme vulnerability), which generates unrealistic conditions in terms of human activities. Contrarily, the SA method allows the differentiation of multiple hazard level zones (i.e. has a more sophisticated indexing), which is indispensable in an area of intense human presence. Thirdly, a high level of spatial correlation exists between the transit time map and the SA map. Fourthly, the high spatial resolution of the SA map allows the detailed mapping and localization of karstic morphological features that profoundly influence water dynamics in the studied site. Therefore, we believe, that SA approach is an adequate candidate for the delineation of karst protection zones in areas similar to the Mecsek Karst.

Our results demonstrated the applicability of the SA risk mapping on vulnerability zonation. The outcomes of the current study presented a new, refined and upgraded mapping approach which may contribute to the mitigation of pollution risk to the aquifer. We believe that internal protection zones with transit times of less than 20 days should be legally defined and its protection and conservation status should be enforced by legal means to restrict human interventions that pose potential pollution on local aquifers. Revised risk zonation, additionally, supported with appropriate legal consequences, likely minimizes undesired human activities within the zone of protection, hence maintaining water quality that complies with the protection acts.

The protection is particularly important in the highly vulnerable zones of I and II (Zwahlen, 2004). The potential threats to the groundwater likely appear in and around populated areas, recreational facilities and the roads. Due to the efforts to mitigate risks and contaminant load to the aquifer, several infrastructural developments have been accomplished in the study area, among which perhaps the most important has been the construction of the sewerage system of the zoo. Nonetheless, additional infrastructural developments are also indispensable in the area of the Mecsek Karst, e.g. secured road construction, reduced agricultural interventions and limited use of herbicides, pesticides, fungicides and fertilizers. 


\section{ACKNOWLEDGMENT}

The project has been supported by the European Union, co-financed by the European Social Fund: EFOP3.6.1.-16-2016-00004 and NRDI Fund, grant number 20765-3/2019/ FEKUTSTRAT. This research was also funded by the Higher Education Institutional Excellence Program of Ministry of Human Capacities (Hungary), the Hungarian Scientific Research Fund (project GINOP-2.3.2-15-2016-00055) and the Hungarian-Slovenia collaborative project "Possible ecological control of flood hazard in the hill regions of Hungary and Slovenia" (contract no SNN 125727, National Office for Research, Development and Innovation). The authors are indebted to the Mecsekérc Zrt. for providing background information on tracer tests and Prof. Dénes Lóczy (University of Pécs) for proofreading the original manuscript.

\section{REFERENCES}

Adams, B., Foster, S., 1992. Land-surface zoning for groundwater protection. Journal of the Institution of Water and Environmental Management, 6(3): 312-320. https://doi.org/10.1111/j.1747-6593.1992. tb00755.x

Albinet, M., Margat, J., 1970. Cartographie de la vulnerabilite ala pollution des nappes d'eau souterraine [Contamination vulnerability mapping of groundwater]. Bulletin de la Bureau de Recherches G'eologiques et Mini'eres 2nd serves, 3: 13-22.

Andreo, B., Ravbar, N., Vias, J.M., 2009. Source vulnerability mapping in carbonate (karst) aquifers by extension of the COP method:application to pilot sites. Hydrogeology Journal, 17(3): 749-758. https://doi.org/10.1007/s10040-008-0391-1

Barabás, A., Barabásné-Stuhl, Á., 1998. A Mecsek és környéke perm képződményeinek rétegtana [Stratigraphy of Permian formations of the Mecsek Mts. and their surroundings]. In: Bérczi, I., Jámbor, Á. (Eds.) Magyarország képződményeinek rétegtana. MOL Rt. - MÁFI, Budapest, pp. 187-215.

Barreto, S., Bártfai, B., Engloner, A., Liptay, Á.Z., Madarász, T., Vargha, M., 2017. Water in Hungary. Status overview for the National Water Programme of the Hungarian Academy of Sciences. Hungarian Academy of Sciences, Budapest, pp. 97.

Bauer, M., Tóth, T.M., 2015. Modelling microfracture geometry to assess the function of a karst system (Vízfó spring catchment area, Western Mecsek Mountains, Hungary). Geologia Croatica, 68(1): 11-23. https:// doi.org/10.4154/GC.2015.02

Bötkös, T., 2006. Precipitation trends in Pécs. In: HalasiKun, G.J. (Ed.) Sustainable Development in Central Europe. Pollution and Water Resources, Columbia University Seminar Proceedings, Volume XXXVI, Pécs, pp. 171-177.
Chikán, G., Chikán, G.-né., Kókai, A., 1984. A NyugatiMecsek földtani térképe. 1:25.000. [Geological map of the Western Mecsek. 1:25.000]. Magyar Állami Földtani Intézet [Map].

Chikán, G., Budai, T. (Eds.), 2005. Magyarország földtani térképe $M=1: 100000$. [Geological map of Hungary 1:10.000] L-34-61. Magyar Állami Földtani Intézet [Map].

Csontos, L., Marton, E., Worum, G., Benkovics, I., 2002. Geodynamics of SW Pannonian inselbergs (Mecsek and Villany Mts, SW Hungary): Inferences from a complex structural analysis. EGU Stephan Mueller Special Publication Series, 3: 227-245. http://dx.doi. org/10.5194/smsps-3-227-2002

Csurgó, G., Szulimán, S., 2017. Az uránbányászati Bányatérségek szivárgáshidraulikai modellezése. [Leakage hydraulic modeling of uranium mining areas). No:29-31/2017, Mecsekérc Zrt. Archive, Pécs, 75 pp.

Daly, D., Dassargues, A., Drew, D., Dunne, S., Goldscheider, N., Neale, S., Popescu, I., Zwahlen, F., 2002. Main concepts of the "European approach" to karstgroundwatervulnerability assessment and mapping. Hydrogeology Journal, 10: 340-345. https://doi. org/10.1007/s10040-001-0185-1

Davis, A.D., Long, A.J., Wireman, M., 2002. KARSTIC: a sensitive method for carbonate aquifers in karst terrain. Environmental Geology, 42: 65-72. https:// doi.org/10.1007/S00254-002-0531-1

Dörfliger, N., Zwahlen, F., 1998. Practical guide: groundwater vulnerability mapping in karstic regions (EPIK). Swiss Agency for the Environment, Forests and Landscape, Bern, 56 pp. European Commission, 2007. The EU Water Framework Directive. https:/ec.europa.eu/environment/pubs/pdf/ factsheets/wfd/en.pdf. [20 ${ }^{\text {th }}$ April 2020]. 
Ford, D.C., Williams, P.W., 1989. Karst Geomorphology and Hydrology. Unwin Hyman, London, 601 pp.

Foster, S., 1987. Fundamental concepts in aquifer vulnerability, pollution risk and protection strategy. In: Duijvenbooden W. van, H.G. van, Waegeningh, H.G. van, (Eds.), Vulnerability of soil and groundwater to pollutants, Proceedings and Information, 38, Noordwijk aan Zee, 30 March - 3 April 1987, pp. 69-86.

Foster, S., Hirata, R., Andreo, B., 2013. The aquifer pollution vulnerability concept: aid or impedimentin promoting groundwater protection?. Hydrogeology Journal, 21(7): 1389-1392. http://dx.doi. org/10.1007/s10040-013-1019-7

Fülöp, J., 1994. Magyarország geológiája. Paleozoikum II. [Geology of Hungary. Paleozoic II.]. Akadémiai K., Budapest, 445 pp.

Goldscheider, N., 2005. Karst groundwater vulnerability mapping: Application of a new method in the Swabian Alb, Germany. Hydrogeology Journal, 13(4): 555-564. https://doi.org/10.1007/s10040-003-0291-3

Goldscheider, N., 2010. Delineation of spring protection zones.- In: Kresic N., Stevanovic, Z. (Eds.), Groundwater Hydrology of Springs. Centre of Hydrogeology, University of Neuchatel, Neuchatel, Switzerland, pp. 305-338. https://doi.org/10.1016/B978-1-85617502-9.00008-6

Goldscheider, N., Hötzl, H., Fries, W., Jordan, P., 2001. Validation of a vulnerability map (EPIK) with tracer tests. In: Mudry, J., Zwahlen, F. (Eds.), 7th Conference on Limestone Hydrology and Fissured Media, Besancon $20^{\text {th }}-22^{\text {nd }}$ September 2001, pp 167-170.

Goldscheider, N., Klute, M., Sturm, S., Hötzl, H., 2000. The PI method - A GIS-based approach to mapping groundwater vulnerability with special consideration of karst aquifers. Zeitschrift für angewandte Geologie, 46(3): 157-166.

Hartmann, A., Goldscheider, N., Wagener, T., Lange, J., Weiler, M., 2014. Karst water resources in a changing world: Review of hydrological modeling approaches. Reviews of

Geophysics, 52(3): 218-242. https://doi. org/10.1002/2013RG000443

Hoyk, E., 2001. A tervezett Nyugat-Mecsek Tájvédelmi Körzet természetközeli állapotának elemzése talajainak vizsgálata alapján. [Analysis of the nearnature status of the planned Western Mecsek Landscape Protection Area based on the examination of soils]. Karsztfejlödés, 6: 221-232.

Iván, V., Mádl-Szőnyi, J., 2019. Process-based resource vulnerability assessment on the example of GömörTorna Karst, Hungary and Slovakia. In: Alberti, L., Bonomi, T., Masetti, M., (Eds.), Flowpath 2019: Na- tional Meeting of Hydrogeology, Conference proceedings, Milano, $12^{\text {nd }}-14^{\text {th }}$ June 2019 , pp. 93-94.

Iván, V., Móga, J., Fehér, K., Miklós, B., 2011. Karszt-sérülékenységi vizsgálatok a bükki

Kis-fennsík karsztján. [Karst vulnerability assessment of Kis-fennsík (Bükk Mountain)] Karsztfejlődés, XVI: 167-183.

Jakada, H., Chen, Z., Luo, Z., Zhou, H., Luo, M., Ibrahim, A., Tanko, N., 2019. Coupling Intrinsic Vulnerability Mapping and Tracer Test for Source Vulnerability and Risk Assessment in a Karst Catchment Based on EPIK Method: A Case Study for the Xingshan County, Southern China. Arabian Journal for Science and Engineering, 44: 377-389. https://doi. org/10.1007/s13369-0183392-y

Jámbor, A., 1969. Karbon képződmények a Mecsek és a Villányi-hegység közötti területen. [Carboniferous deposits in the area between the Mecsek and Villány Mountains]. MÁFI Évi Jelentése az 1967. évről \{Annual Report of the Geological Institute of Hungary, 1967\}, 215-221.

Jeannin, P.Y., Cornaton, F., Zwahlen, F., Perrochet, P., 2001. VULK: a tool for intrinsic vulnerability assessment and validation. In: Mudry, J., Zwahlen, F. (Eds.), 7th Conference on Limestone Hydrology and Fissured Media, Besancon, 20 ${ }^{\text {th }}-22^{\text {nd }}$ September 2001, pp 185-188.

Jeannin, P.Y., Eichenberger, U., Sinreich, M., Vouillamoz, J., Malard, A., Weber, E., 2013. KARSYS: a pragmatic approach to karst hydrogeological system conceptualisation. Assessment of groundwater reserves and resources in Switzerland. Environmental Earth Sciences, 69(3): 999-1013. https://doi.org/10.1007/ s12665-012-1983-6

Kavouri, K., Plagnes, V., Tremoulet, J., Dörfliger, N., Rejiba, F., Marchet, P., 2011. PaPRIKa: a method for estimating karst resource and sourcevulnerabilityapplication to the Ouysse karst system(southwest France). Hydrogeology Journal, 19(2): 339-353. http://dx.doi.org/10.1007/s10040-010-0688-8

Konrád, Gy., Sebe, K., 2010. Fiatal tektonikai jelenségek új észlelései a NyugatiMecsekben és környezetében [New details of young tectonic phenomena in the Western Mecsek Mts and their surroundings]. Földtani Közlöny, 140(2): 135-162.

Konrád, Gy., Sebe, K., Halász, A., Halmai, A., 2010. A Délkelet-Dunántúl földtani fejlődéstörténete - recens analógiák. Földrajzi Közlemények, CXXVIII. évf. 4. sz. 251-265.

Laborczi, A., Szatmári, G., Takács, K., Pásztor, L., 2016. Mapping of topsoil texture in Hungary using classification trees. Journal of Maps, 12(5): 999-1009. https://doi.org/10.1080/17445647.2015.1113896 
Laborczi, A., Szatmári, G., Kaposi, A. D., Pásztor, L., 2018. Comparison of soil texture maps synthetized from standard depth layers with directly compiled products. GEODERMA, 352. http://dx.doi. org/10.1016/j.geoderma.2018.01.020

Lóczy, D., 2006. Nemzetközi áttekintés a karsztok sérülékenységének minősítési módszereiről. [International overview of methods of rating karst vulnerabilities]. Karsztfejlődés, XI: 209-221.

Margat, J., 1968. Vulnerabilit'e des nappes d'eau souterraine 'a la pollution [Contamination vulnerability mapping of groundwater]. Bureau de Recherches G'eologiques et Mini'eres, Orleans. Bases de al cartographie (Doc.) 68 SGC 198HYD, BRGM, Orleans.

Marín, A.I., Ravbar, N., Kovačič, G., Andreo, B., Petrič, M., 2014. Application of Methods for Resource and Source Vulnerability Mapping in the Orehek Karst Aquifer, SW Slovenia. In: Mudry, J., Zwahlen, F., Bertrand, C., LaMoreaux, J. (Eds), H2Karst Research in Limestone Hydrogeology. Environmental Earth Sciences, Springer, Cham, pp. 139-150. https://doi.org/10.1007/978-3-319-06139-9_10

Marín, A.I., Andreo, B., Mudarra, M., 2015. Vulnerability mapping and protection zoning of karst springs. Validation by multitracer tests. Science of The Total Environment, 532: 435-446. https:/doi. org/10.1016/j.scitotenv.2015.05.029

Morschhauser, T., Salamon-Albert, É., 2001. Isoecological curves on characterising the ecotypes central Mecsaek MTS of Hungary. Acta Botanica Hungarica, 43(1-2): 189-199. https://doi.org/10.1556/ ABot.43.2001.1-2.11

Péczely, Gy., 2009. Éghajlattan [Climatology]. Nemzeti Tankönyvkiadó, Budapest, 336 pp.

Ravbar, N., Goldscheider, N., 2007. Proposed methodology of vulnerability and contamination risk mapping for the protection of karst aquifers in Slovenia. Acta Carsologica, 36(3): 461-475. https://doi. org/10.3986/ac.v36i3.174

Ravbar, N., Goldscheider, N., 2009. Comparative application of four methods of groundwater vulnerability mapping in a Slovene karst catchment. Hydrogeology Journal, 17(3): 725-733. https://doi.org/10.1007/ s10040-008-0368-0

Rónaki, L., 1973. A mecseki karszt 1:10 000-es méretarányú vízföldtani, morfológiai és speleológiai térképe. [1:10.000 Hydrological, Morphological and Speleological map of the Mecsek Karst]. Hirdológiai tájékoztató, 78-81.
Rónaki, L., 2007. A Mecseki karszton történt víznyomjelzések áttekintése. [Overview of the water tracing in the Mecsek karst]. Karszfejlődés XII. Szombathely, 91-103.

Stevanovic, Z., 2019. Karst waters in potable water supply: a global scale overview. Environmental Earth Sciences, 78: 23. https://link.springer.com/article/1 0.1007\%2Fs12665-019-8670-9

Szőnyi-Mádl, J., Füle, L., 1998. Groundwater vulnerability assessment of the SW TransDanubian Central Range, Hungary. Environmental Geology, 35(1): 9-18. https://doi.org/10.1007/s002540050287

Tóth, Á., Simon, Sz., Galsa, A., Havril, T., Monteiro Santos, F.A., Müller, I., MádlSzőnyi, J., 2017. Vulnerability assessment of groundwater-dependent ecosystems based on integrated groundwater flow modell construction. 19th EGU General Assembly, EGU2017, proceedings from the conference, Vienna, $23^{\text {rd }}-28^{\text {th }}$ April 2017, p.10297.

Turk, J., Malard, A., Jeannin, P.Y., Petric, M., Gabrovsek, F., Ravbar, N., Vouillamoz, J., Slabe, T., Sordet, V., 2014. Hydrogeological interpretation of the alpine karst massif by application of a Karsys approach (Kanin case study, Julian Alps). Hydrological Processes, 29(8): 1986-1998. https://doi.org/10.1002/ hyp. 10313

Turpaud, P., Zini, L., Ravbar, N., Cucchi, F., Petrič, M., Urbanc, J., 2018. Development of a Protocol for the Karst Water Source Protection Zoning: Application to the Classical Karst Region (NE Italy and SW Slovenia). Water Resources Management, 32: 19531968. https://doi.org/10.1007/s11269-017-1882-4

Vias, J.M., Andreo, B., Perles, M.J., Carrasco, F., Vadillo, I., Jimenez, P., 2006. Proposed method for groundwater vulnerability mappingin carbonate (karstic) aquifers: the COP method. Hydrogeology Journal, 14: 912-925. https://doi.org/10.1007/s10040-0060023-6

Vozárová, A., Ebner, F., Kovács, S., Kräutner, H.G., Szederkényi, T., Kristić, B, Sremac, J., Aljinovič, D., Novak, M., Skaberne, D., 2009. Late Variscan (Carboniferous to Permian) environments in the Circum Pannonian Region. Geologica Carpathica, 60(1): 71-104. https://doi.org/10.2478/v10096-0090002-7

Zwahlen, F., 2004. COST Action 620: vulnerability and risk mapping for the protection of carbonate (Karst) Aquifers. Final report, European Water Framework Directive [Report]. European 632 Commission, 297 pp. 